\title{
Praktik Pembelajaran Keterampilan Berbicara Di Masa Pandemi Covid-19
}

\author{
Rizki Amalia Sholihah \\ Institut Agama Islam Sunan Giri Ponorogo \\ Jl. Batoro Katong no 32 Kabupaten Ponorogo Provinsi Jawa Timur \\ Correspondence Email: rizkiamalias88@gmail.com
}

\begin{abstract}
This study aims to describe the practice of language learning, namely students' speaking ability during the pandemic period using an online learning system and the obstacles it faces. This research is descriptive qualitative research with a case study research type. The subjects in this study were 13 students of PGMI Insuri Ponorogo who took the Indonesian Language 1 course in the third semester. Learning speaking skills is carried out with four types of speaking practices, namely reading stories, reading announcements, giving speeches, and discussing. Of the four practices, it's known that if there is no speaking practice, namely reading stories, reading announcements, and making speeches, only four aspects of assessment are fold, namely (1) vocal clarity; (2) correct intonation; (3) accuracy of word choice (diction); and (4) sentence structure (speech). This is because there is no interaction with other speakers, no need to convey or express opinions, and not required to show data outside of the text to support their speaking skills. In contrast to the ability to discuss which requires 6 aspects, namely (1) fluency in conveying opinions/responses; (2) vocal clarity; (3) correct intonation; (4) accuracy of word choice (diction); (5) sentence structure (speech); and (6) accuracy in expressing ideas accompanied by textual data in practice. In the discussion practice, students' speaking ability is also trained better without dependence on reading texts. However, there is still one aspect that cannot be involved in assessing learning practices using voice message media, namely eye contact with listeners. One aspect of this is also one of the obstacles faced in online learning that only uses voice message media. Unrecognizing expressions and gestures when carrying out practice also prevent listeners (lecturers) from including them in the assessment aspect.
\end{abstract}

\section{Keywords:}

Covid-19; language; learning; online; speaking skill

\begin{abstract}
Abstrak
Penelitian ini bertujuan untuk mendeskripsikan praktik dalam pembelajaran bahasa yaitu kemampuan berbicara mahasiswa selama masa pandemi berlangsung dengan sistem pembelajaran daring berikut dengan kendala yang dihadapinya. Penelitian ini adalah penelitian kualitatif deskriptif dengan jenis penelitian studi kasus. Subjek dalam penelitian ini yaitu mahasiswa PGMI Insuri Ponorogo sejumlah 13 mahasiswa yang mengikuti mata kuliah Bahasa Indonesia 1 di semester III. Praktik pembelajaran keterampilan berbicara dilakukan dengan empat jenis praktik berbicara yaitu membaca cerita, membaca pengumuman, berpidato, dan berdiskusi. Dari empat praktik tersebut diketahui jika tidak praktik berbicara yaitu membaca cerita, membaca pengumuman, dan berpidato hanya melibatkan 4 aspek penilaian yaitu (1) kejelasan vokal; (2) ketepatan intonasi; (3) ketepatan pilihan kata (diksi); dan (4) struktur kalimat (tuturan). Hal ini dikarenakan tidak ada interaksi yang dilakukan dengan pembicara lain, tidak perlu menyampaikan atau mengemukakan pendapat, dan tidak diwajibkan menunjukkan data di luar isi teks naskah untuk mendukung kemampuan berbicaranya. Berbeda dengan kemampuan diskusi yang menuntut adanya 6 aspek yaitu (1) kelancaran menyampaikan pendapat/tanggapan; (2) kejelasan vokal; (3) ketepatan intonasi; (4) ketepatan pilihan kata (diksi); (5) struktur kalimat (tuturan); dan (6) ketepatan mengungkapkan gagasan disertai data tekstual dalam praktiknya. Pada praktik diskusi juga kemampuan mahasiswa dalam berbicara dilatih lebih baik tanpa ada ketergantungan pada teks bacaan. Namun masih terdapat satu aspek yang tidak bisa dilibatkan dalam penilaian praktik pembelajaran dari dengan media pesan suara yaitu kontak mata dengan pendengar. Satu aspek ini juga yang kemudian menjadi salah satu kendala yang dihadapi pada pembelajaran daring yang hanya menggunakan media
\end{abstract}


pesan suara dalam pembelajarannya. Tidak dapat diketahuinya ekspresi dan gesture saat melaksanakan praktik juga membuat pendengar (dosen) tidak memasukkan ke dalam aspek penilaian.

Kata Kunci:

Bahasa; keterampilan berbicara; Covid-19; daring; pembelajaran

\section{Pendahuluan}

Penyebaran virus Corona yang masif di berbagai negara telah memaksa kita untuk melihat fakta bahwa dunia sedang berubah. Kita bisa melihat bagaimana perubahan teknologi, ekonomi, politik dan pendidikan di tengah krisis akibat Covid-19. Perubahan menuntut kita untuk siap, bereaksi dengan sikap dan tindakan, dan selalu mempelajari hal-hal baru. ${ }^{1}$ Data terbaru total kasus Covid-19 di dunia terkonfirmasi sebanyak 35.118.424 kasus dikutip dari Worldometers, Minggu, 4 Oktober 2020. ${ }^{2}$ Hal ini tentu menjadi fokus penting berbagai pihak di seluruh belahan dunia, termasuk di Indonesia. Selain sektor utama yang "diserang" pendidikan adalah sector lain yang juga mendapat "imbas" akan adanya penyebaran Covid-19 ini.

Pendidikan adalah sektor utama dalam pembangunan bangsa Indonesia. Pendidikan yang berkualitas perlu didukung oleh sumber daya manusia yang berkualitas pula. Hal ini dikarenakan pendidikan adalah kunci berkembangnya sumber daya manusia yang bermutu tinggi. Berdasar pada Keputusan Presiden Nomor 11 tahun 2020 mengenai penetapan kedaruratan kesehatan masyarakat selama covid-19 yang terjadi di Indonesia, maka

${ }^{1}$ Gogot Suharwoto. "Pembelajaran Online di Tengah Pandemi Covid-19, Tantangan yang Mendewasakan,". 2020. Diakses 10 November 2020. https://pusdatin.kemdikbud.go.id/pembelajaranonline-di-tengah-pandemi-covid-19-tantangan-yangmendewasakan/

${ }^{2}$ Dandy Bayu Bramasta. "Update Covid-19 di Dunia 4 Oktober: 35,1 Juta Orang Terinfeksi, 1 Juta Meninggal | WHO Tegur Turki." 4 Oktober 2020.

https:/www.kompas.com/tren/read/2020/10/04 /064657165/update-covid-19-di-dunia-4-oktober-351juta-orang-terinfeksi-1-juta?page $=$ all perlu dilaksanakan upaya untuk menanggulangi keadaan tersebut sesuai dengan aturan perundang-undangan Dirjen Dikti. Upaya tersebut adalah dengan menetapkan bahwa pembelajaran pada tahun ajaran 2020/2021 dan tahun akademik 2020/2021 pada masa pandemi Covid-19 menerapkan metode pembelajaran yang terdapat di perguruan tinggi di semua zona wajib diberlakukan secara online atau dalam jaringan untuk seluruh mata kuliah baik teori maupun praktik. 3 Hal ini juga didukung dengan adanya surat keputusan bersama 4 menteri mengenai kebijakan pendidikan di perguruan tinggi seiring dengan tidak adanya penurunan angka penderita covid-19 yang signifikan pada bulan Juni 2020. Pun jika tetap akan dilaksanakan pembelajaran secara langsung tatap muka, maka perlu memenuhi protokol kesehatan demi mencegah adanya penyebaran Covid-19. ${ }^{4}$ Sejauh ini studi tentang aspek pendidikan yang terpengaruh oleh pandemic COVID-19 lebih terfokus pada aspek yang cakupannya luas. Pertama, menilik pada perlunya penanganan khusus demi tetap berlangsungnya sistem pembelajaran dengan kurikulum yang dapat fleksibel dalam menghadapi masa pandemic ini. ${ }^{5}$ Kedua mengenai kendala

3 Direktorat Jenderal Pendidikan Tinggi Kemdikbud RI, "Buku Panduan Penyelenggaraan Pembelajaran Semester Gasal 2020/2021 Di Perguruan Tinggi," 2020, 29.

Kemdikbud RI.

4 Direktorat Jenderal Pendidikan Tinggi

${ }^{5}$ Akbar Yuli Setianto, "Kurikulum Fleksibel : Jalan Keluar Pembelajaran Di Masa Covid-19," in Belajar Mandiri: Pembelajaran Daring Di Tengah Pandemi Covid-19, ed. Jamaludin (Yayasan Kita Menulis, 2020), kitamenulis.id. 
yang terjadi selama pembelajaran secara daring $^{6}$, lalu berikutnya mengenai analisis pembelajaran bagi guru $^{7}$ maupun pemimpin. ${ }^{8}$

Dalam kegiatan pembelajaran, kondisi yang mengharuskan pembelajaran secara daring, tentu berdampak pada sistem pembelajaran dan seluruh komponen yang ada di dalamnya. Termasuk dalam praktik pembelajaran yang biasanya mengharuskan mahasiswa untuk melakukannya secara tatap muka, maka dialihkan menjadi pembelajaran secara daring. Hal ini pula yang harus dialami oleh mahasiswa program studi PGMI Insuri Ponorogo yang dalam beberapa pembelajarannya juga melaksanakan kuliah secara non tatap muka. Salah satu mata kuliah yang melaksanakan sistem pembelajaran ini adalah mata kuliah Bahasa Indonesia 1 yang di dalamnya terdapat materi 4 keterampilan berbahasa, yaitu menyimak, berbicara, membaca, dan menulis. Dari empat keterampilan berbahasa tersebut dibagi menjadi dua jenis kemampuan yaitu, kemampuan reseptif dan produktif. Kemampuan reseptif meliputi kemampuan mendengar dan membaca, sedangkan kemampuan produktif adalah kemampuan berbicara dan menulis. Pada pembelajaran keterampilan berbahasa produktif, selain perlu menguasai teori dengan baik, memerlukan praktik dalam penerapannya.

\footnotetext{
${ }^{6}$ Jamaludin, "Kendala Pembelajaran Daring Di Tengah Pandemi Covid-19," in Belajar Mandiri: Pembelajaran Daring Di Tengah Pandemi Covid-19, ed. Janner Simarmata (Yayasan Kita Menulis, 2020), 107-12, kitamenulis.id.

${ }^{7}$ Hilna Putria, Luthfi Hamdani Maula, and Din Azwar Uswatun, “Analisis Proses Pembelajaran Dalam Jaringan (DARING) Masa Pandemi COVID-19 Pada Guru Sekolah Dasar," BASICEDU 4, no. 4 (2020), https://doi.org/10.31004.

8 Wahyudin Darmalaksana et al., "Analisis Pembelajaran Online Masa WFH Pandemic Covid-19 Sebagai Tantangan Pemimpin Digital Abad 21," Karya
}

Penelitian ini bertujuan untuk mendeskripsikan praktik dalam pembelajaran salah satu kemampuan berbahasa secara produktif yaitu kemampuan berbicara mahasiswa selama masa pandemic berlangsung dengan sistem pembelajaran daring berikut dengan kendala yang dihadapinya. Kemampuan berbicara berkaitan dengan pengucapan kata-kata yang bertujuan untuk menyampaikan apa yang akan disampaikan baik itu perasaan, ide atau gagasan. Keterampilan berbicara bukanlah jenis keterampilan yang dapat diwariskan dari generasi ke generasi, meskipun hampir semua orang dapat berbicara secara alami, namun berbicara merupakan salah satu bentuk keterampilan produktif yang terjadi secara langsung dan ekspresif dibandingkan dengan kegiatan bahasa lainnya, sehingga relatif sulit untuk menerapkan keterampilan tersebut dalam proses pembelajaran. ${ }^{9}$ Diharapkan dengan adanya pembelajaran keterampilan berbicara, nantinya mahasiswa dapat meningkatkan penghasilannya untuk menopang perekonomian keluarga, misalnya dengan menjadi motivator, menjadi pembicara di seminar, atau menjadi pembawa acara selain menjadi guru sebagai tugas utamanya.

Penelitian mengenai kemampuan berbicara telah banyak dilakukan misalnya pada siswa SMA di Denpasar ${ }^{10}$, pada siswa SD di Ponorogo", siswa SMK di

Tulis Ilmiah (KTI) Masa Work From Home (WFH) Covid-19 UIN Sunan Gunung Djati Bandung Tahun 2020 1, no. 1 (2020): 1-12.

${ }^{9}$ Ni Gusti Ayu Sinta Dewi, Sang Ayu Putu Sriasih, and I Nyoman Sudiana, "Teknik Penilaian Keterampilan Berbicara Dalam Pembelajaran Bahasa Indonesia Di SMA Negeri 4 Denpasar," E-Journal Pendidikan Bahasa Dan Sastra Indonesia 7, no. 2 (2017): 1-12.

\footnotetext{
${ }^{10}$ Sinta Dewi, Sriasih, and Sudiana.
}

11 Rizki Amalia Sholihah, "Metode Suggestopedia Dengan Teknik Bermain Peran Atau Role Playing Dalam Pembelajaran Keterampilan 
Kediri $^{12}$, dan pada siswa SMP di Surakarta ${ }^{13}$. Dari beberapa penelitian tersebut, belum terdapat penelitian yang mengkaji mengenai praktik berbicara pada pembelajaran keterampilan berbicara selama masa pandemic dengan tanpa tatap muka dan memanfaatkan media elektronik yaitu aplikasi Whatsapp yang memiliki fasilitas voice note atau pesan suara. Penggunaan pesan suara sebagai media praktik pembelajaran keterampilan berbicara tentu memiliki kelebihan dan kekurangan yang kemudian juga terdapat beberapa aspek penilaian yang dapat diberikan oleh dosen dari hasil praktek tersebut. Penelitian ini merupakan penelitian kualitatif yang merujuk pada analisis data nonmatematis, dengan hasil temuan berupa data yang dikumpulkan dengan berbagai sarana, di antaranya wawancara, pengamatan, dokumen atau arsip, dan tes $^{14}$. Pada penelitian ini data dikumpulkan dengan dokumen berupa pesan suara praktik berbicara yang berasal dari subjek penelitian yaitu 13 mahasiswa program studi PGMI yang terbagi menjadi empat jenis praktik berbicara. Penelitian penelitian kualitatif sendiri adalah untuk memahami kondisi suatu konteks dengan mendeskripsikan dengan detail dan mendalam mengenai gambaran keadaaan pada suatu konteks yang alami, tentang yang sebenarnya terjadi di lapangan studi $^{15}$. Jenis penelitian ini adalah deskriptif dengan jenis penelitian studi kasus untuk mengumpulkan dan menganalisis data sehubungan dengan

Berbicara Bahasa Indonesia Siswa Sekolah Dasar," AlAdabiya: Jurnal Kebudayaan Dan Keagamaan 10, no. 1 (2017): 1-24.

12 Nur Lailiyah and Widi Wulansari, "Peningkatan Keterampilan Berbicara Melalui Metode Diskusi Kelompok Model Tanam Paksa Siswa Kelas X Pemasaran 1 SMK PGRI 2 Kediri," JP (Jurnal Pendidikan): Teori Dan Praktik 1, no. 2 (2017): 16673.

${ }^{13}$ Norma Kusmintayu, Sarwiji Suwandi, and Atikah Anindyarini, "Penerapan Metode Mind suatu kasus ${ }^{16}$ yaitu dalam penelitian ini adalah praktik keterampilan berbahasa (mendengarkan) pada mahasiswa prodi PGMI Insuri Ponorogo yang mengikuti mata kuliah Bahasa Indonesia 1 di semester III.

\section{Hasil dan Pembahasan}

Penelitian ini dilakukan dalam satu kali pembelajaran yang berlangsung dalam waktu tiga hari yaitu tanggal $15-17$ September 2020 dengan pembelajaran daring. Waktu tiga hari yang diperlukan adakah dikarenakan dalam pembelajaran tidak semua mahasiswa mampu mengumpulkan hasil praktik yang dilakukan dalam waktu bersamaan. Dosen memberikan waktu maksimal dua hari untuk melakukan praktik dan hasil penilaian tersebut dberikan pada keesokan harinya. Dalam praktik pembelajaran keterampilan berbicara, mahasiswa diberikan tugas empat jenis praktik yaitu membaca cerita, berpidato, dan membaca pengumuman yang dilakukan oleh masing-masing 1 mahasiswa dan praktik berdiskusi yang dilakukan secara berkelompok sebanyak 3 mahasiswa dalam satu diskusi. Total mahasiswa yang dijadikan subjek penelitian ini adalah 13 mahasiswa dengan rincian pembagian tugas praktik sebagai berikut.

Tabel 1. Pembagian Tugas Praktik Keterampilan Berbicara

\begin{tabular}{cl}
\hline No & Jenis Praktik \\
\hline 1. & Membaca cerita \\
\hline
\end{tabular}

Mapping Untuk Meningkatkan Keterampilan Berbicara Pada Siswa Sekolah Menengah Pertama," Jurnal Penelitian Bahasa, Sastra Indonesia, Dan Pengajarannya 1, no. 1 (2012): 120-29.

${ }^{14}$ Hardani Ahyar et al., Buku Metode Penelitian Kualitatif \& Kuantitatif, 2020.

15 Farida Nugrahani, Metode Penelitian Kualitatif Dalam Penelitian Pendidikan Bahasa, Cakra Book, vol. 1 (Solo, 2014).

16 Ahyar et al., Buku Metode Penelitian Kualitatif \& Kuantitatif. 


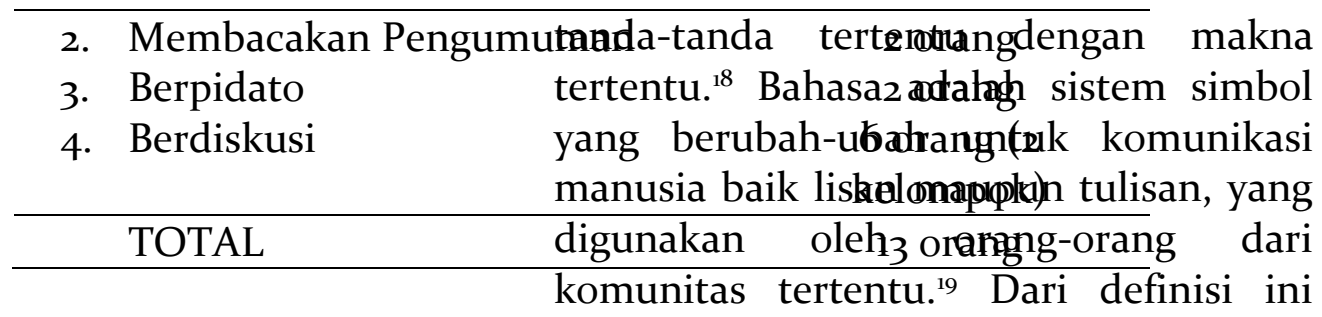

Pada praktiknya, mahasiswa diminta untuk mengumpulkan tugas melalui aplikasi pesan Whatsapp yang terdapat fitur voice note atau pesan suara. Pesan suara yang terdapat pada aplikasi WhatsApp memungkinkan penggunanya untuk berkomunikasi secara langsung dengan kontak dan grup. Pengguna juga dapat menggunakannya untuk menyampaikan informasi penting dan peka waktu. ${ }^{17}$ Penggunaan fitur ini dimaksudkan adalah untuk mempermudah mahasiswa yang lokasi tempat tinggalnya tidak memiliki jangkauan sinyal yang cukup baik dan stabil untuk mengirimkan tugas praktik keterampilan berbicara jika dalam bentuk video. Maka penggunaan pesan suara diharapkan mampu menjadi solusi terbaik dalam praktik pembelajaran ini, juga bentuk kesetaraan bagi seluruh mahasiswa baik yang tinggal di daerah yang terpencil maupun yang tinggal di perkotaan dan terfasilitasi oleh sinyal provider atau wifi dengan baik.

\subsection{Praktik Keterampilan Berbicara}

Bahasa adalah sistem formal dari tanda-tanda yang diatur oleh kombinasi aturan gramatikal guna mengkomunikasikan makna. Definisi ini menekankan fakta bahwa bahasa manusia dapat digambarkan sebagai sistem struktural tertutup yang terdiri dari aturan-aturan yang menghubungkan

\footnotetext{
${ }^{17}$ https://faq.whatsapp.com/android/chats/howto-send-voice-messages/?lang=id

${ }^{18}$ Leonard Bloomfield, An Introduction to The Study of Language (New York: Henry Holt and Company, 1914).
} dapat dijabarkan bahwa: (1) Sistem adalah kata-kata tertulis atau suara yang diucapkan dan diatur dalam urutan tertentu (2) Komunikasi adalah mendengar atau membaca dan menanggapi kata-kata yang diucapkan atau ditulis (3) Berubah-ubah adalah kata "berubah-ubah atau sewenang-wenang" berarti tidak berdasarkan alasan, sistem, atau rencana, dan (4) Simbol adalah huruf atau kata atau suara yang menyarankan ide. Definisi lain yang lebih sederhana mungkin adalah bahasa adalah sistem simbol sewenang-wenang yang membantu orang-orang tertentu dalam sebuah komunitas untuk berkomunikasi dan berinteraksi. Definisi ini berarti itu (1) Setiap bahasa beroperasi dalam sistemnya sendiri (2) Setiap bahasa memiliki simbolsimbolnya sendiri-sendiri, dan (3) Kata "berkomunikasi dan berinteraksi" berarti memahami dan berbicara. $^{20}$ Dapat disimpulkan jika dalam komunikasi terutama lisan, maka kemampuan seseorang dalam berbicara adalah kemampuan yang perlu dikuasai dengan baik oleh seseorang. Karena jika dipahami lebih dalam, pengertian berbicara adalah sebuah keterampilan oral/lisan produktif dan terdiri dari menghasilkan ucapan verbal sistematis untuk menyampaikan makna.

Sebagai seorang calon guru (madrasah ibtidaiyah/pendidikan dasar), mahasiswa dituntut untuk memiliki kemampuan

\footnotetext{
${ }^{19}$ Marriam Bashir; Muhammad Azeem; Ashiq Hussain Dogar, "Factor Effecting Students ' English Speaking Skills," British Journal of Arts and Social Sciences 2, no. January 2011 (2016): 35-50.

${ }^{20}$ Marriam Bashir; Muhammad Azeem; Ashiq Hussain Dogar.
} 
berbicara yang baik merupakan hal yang harus dikuasai oleh seorang guru. Seorang guru perlu memiliki kemampuan yang baik dalam berbicara baik dalam penguasaan teori maupun dalam prakteknya di kehidupan sehari-hari. Terdapat dua penilaian yang dapat dipergunakan pada pembelajaran berbicara, yaitu penilaian proses dan penilaian hasil. Penilaian proses adalah penilaian sikap mahasiswa ketika mengikuti kegiatan pembelajaran selama kegiatan pembelajaran berlangsung. Penilaian hasil adalah penilaian berdasar hasil kerja (praktek) yang dilakukan mahasiswa saat mempraktikkan kompetensi berbicara. Dalam penelitian ini penilaian yang dilakukan adalah penilaian hasil. Terdapat beberapa aspek yang dapat dinilai dari praktik berbicara yaitu (1) kelancaran menyampaikan pendapat/tanggapan; (2) kejelasan vokal; (3) ketepatan intonasi; (4) ketepatan pilihan kata (diksi); (5) struktur kalimat (tuturan); (6) kontak mata dengan pendengar; (7) ketepatan mengungkapkan gagasan disertai data tekstual. ${ }^{21}$

Dalam praktik pembelajaran Bahasa Indonesia, keterampilan berbicara dapat dilatih dengan berbagai jenis praktik, di antaranya yaitu membaca cerita (baik dengan gambar atau tidak), berdiskusi, membaca pengumuman, berpidato, wawancara, dan bermain peran. Namun dalam penelitian ini hanya akan diuraikan mengenai empat praktik dalam pembelajaran keterampilan berbicara mahasiswa prodi PGMI Insuri Ponorogo dengan menggunakan media pesan suara. Media pembelajaran adalah salah satu faktor eksternal yang mempengaruhi keberhasilan kegiatan pembelajaran yang

21 Burhan Nurgiyantoro, Penilaian Dalam Pengajaran Bahasa Dan Sastra Indonesia (Yogyakarta: BPFE, 2001).

22 Numiek Sulistyo Hanum, "Keefektifan ELearning Sebagai Media Pembelajaran (Studi Evaluasi bermanfaat guna melancarkan interaksi antara guru dengan siswa sehingga kegiatan pembelajaran lebih efektif dan efisien. Keberhasilan sebuah media pembelajaran dan ditunjang adanya interaksi maksimal antara guru dan siswa, antara siswa dan berbagai fasilitas pembelajaran, antara siswa dan siswa lainnya, yang menjadikan adanya pola pembelajaran aktif dalam interaksi tersebut. ${ }^{22}$ Dan dalam pembelajaran ini yang digunakan adalah fitur pesan suara.

Media pesan suara digunakan mahasiswa untuk mengirimkan hasil praktik berbicaranya kepada dosen pengampu mata kuliah karena pembelajaran dilaksanakan secara daring sehingga tidak memungkinkan mahasiswa untuk melakukan praktik secara langsung tatap muka. Langkah pembelajaran yang dilakukan oleh dosen dan mahasiswa dalam menggunakan media pembelajaran pesan suara adalah sebagai berikut yaitu:

a. Dosen menentukan jenis praktik berbicara yang akan dipraktekkan yaitu empat jenis (membaca cerita, membaca berpidato, dan diskusi).

b. Dosen memilih secara acak mahasiswa yang akan mempraktekkan keterampilan berbicara dengan ketentuan jika mendapat bagian untuk mempraktikkan membaca cerita, membaca pengumuman, dan berpidato, berarti praktik dilaksanakan secara individu. Jika mendapat bagian praktik diskusi, maka akan berkelompok 3 orang dengan rincian 1 moderator dan 2 pembahas.

Model Pembelajaran e-Learning SMK Telkom Sandhy Putra Purwokerto)," Jurnal Pendidikan Vokasi 3, no. 1 (2013): 90-102, https://doi.org/10.21831/jpv.v3i1.1584. 
c. Mahasiswa kemudian menentukan naskah yang akan digunakan dalam praktik berbicara.

d. Siswa merekam praktik berbicara via pesan suara dan dikirimkan ke grup Whatsapp untuk dikoreksi oleh dosen.

e. Dosen mengoreksi hasil praktik keterampilan berbicara.

f. Hasil penilaian dibagikan dan didiskusikan kendala dan kekurangan yang terjadi selama pembelajaran.

\subsection{Praktik Membaca Cerita}

Tabel 2. Praktik Membaca Cerita

\begin{tabular}{|c|l|c|c|c|}
\hline \multirow{2}{*}{ No } & \multicolumn{2}{|c|}{ Aspek Penilaian } & \multicolumn{3}{c|}{ Kode Mahasiswa } \\
\cline { 3 - 5 } & & $\mathrm{CR}_{\mathbf{1}}$ & $\mathrm{CR}_{2}$ & $\mathrm{CR}_{3}$ \\
\hline $\mathbf{1 .}$ & Kejelasan vokal & $\mathbf{2}$ & 3 & 4 \\
\hline 2. & Ketepatan intonasi & $\mathbf{2}$ & $\mathbf{2}$ & 4 \\
\hline 3. & Ketepatan pilihan kata & 3 & 3 & 3 \\
\hline 4. & Struktur kalimat & 3 & 4 & 4 \\
\hline & TOTAL & 10 & 12 & 15 \\
\hline
\end{tabular}

Keterangan nilai:

$\begin{array}{ll}4 & \text { : baik sekali } \\ 3 & \text { : baik } \\ 2 & \text { : cukup } \\ 1 & \text { : kurang }\end{array}$

Berdasarkan hasil penilaian tersebut, dari 3 mahasiswa, pada aspek ketepatan pilihan kata dan struktur kalimat, mendapatkan hasil yang baik dan baik sekali. Hal ini menunjukkan kemampuan mahasiswa dalam memilih diksi dan membuat susunan kalimat sesuai dengan strukturnya sudah baik. Pada dua aspek lainnya, yaitu ketepatan intonasi, terdapat 2 mahasiswa yang memiliki kemampuan cukup. Hal ini dikarenakan, dalam membaca cerita, mahasiswa terlalu cepat dan tidak memperhatikan tanda baca, sehingga intonasi tidak jelas dan tidak

\footnotetext{
${ }^{23}$ Suwarti Ningsih, "Peningkatan Keterampilan Berbicara Melalui Metode Bercerita Siswa Kelas III
}

Bercerita adalah menuturkan sesuatu yang mengisahkan tentang perbuatan atau suatu kejadian secara lisan dalam upaya untuk mengembangkan potensi kemampuan berbahasa. ${ }^{23}$ Dalam praktik membaca cerita, mahasiswa diminta untuk membacakan cerita pendek berupa fabel. Terdapat 4 aspek dari 7 aspek dalam keterampilan berbicara yang dinilai dalam membaca cerita yaitu (1) kejelasan vokal; (2) ketepatan intonasi; (3) ketepatan pilihan kata (diksi); dan (4) struktur kalimat (tuturan). Berikut hasil penilaian praktik membaca cerita. 
Mahasiswa CR 3 mempunyai kejelasan vokal yang baik, suara lantang, dan memiliki ketepatan intonasi yang baik pula, sehingga pembacaan cerita terasa menyenangkan dan pesan yang disampaikan cerita tersebut dapat dinikmati dengan baik.

\subsection{Praktik Membaca Pengumuman}

Pengumuman adalah pesan atau informasi yang disampaikan kepada masyarakat umum. $^{24}$ Dalam praktik membaca pengumuman, mahasiswa diminta untuk membacakan sebuah pengumuman secara lantang dengan tujuan agar banyak orang yang akan dijangkau oleh si pemberi pengumuman. Jadi, semakin banyak yang dapat mendengar, tentu akan semakin baik sebuah pengumuman tersebut disampaikan. Aspek yang dinilai sama dengan penilaian membaca cerita yaitu (1) kejelasan vokal; (2) ketepatan intonasi; (3) ketepatan pilihan kata (diksi); dan (4) struktur kalimat (tuturan).

Tabel 3. Praktik Membaca Pengumuman

\begin{tabular}{|c|c|c|c|}
\hline \multirow{2}{*}{ No } & \multirow{2}{*}{ Aspek Penilaian } & \multicolumn{2}{|c|}{ Kode Mahasiswa } \\
\hline & & $\mathrm{PU}_{1}$ & $\mathrm{PU}_{2}$ \\
\hline & Kejelasan vokal & 2 & 3 \\
\hline 2. & Ketepatan intonasi & 2 & 3 \\
\hline 3. & Ketepatan pilihan kata & 3 & 3 \\
\hline & Struktur kalimat & 3 & 3 \\
\hline & TOTAL & 10 & 12 \\
\hline
\end{tabular}

Keterangan nilai:

4 : baik sekali

3 : baik

2 : cukup

1 : kurang

Berdasar hasil penilaian tersebut, diketahui jika mahasiswa PU1 pada aspek kejelasan vokal dan intonasi masih kurang yaitu vokal yang pelan dan kurang jelas dalam pengucapan huruf. Intonasi yang digunakan juga bukan intonasi layaknya sebuah pengumuman. Kurangnya dua aspek tersebut tentu akan mempengaruhi sampai tidaknya sebuah informasi atau berita yang seharusnya disampaikan dengan lantang dan jelas dengan harapan mampu didengar oleh banyak khalayak.

Mahasiswa PU2 lebih baik dalam aspek kejelasan vokal dan intonasi walaupun belum bisa dianggap baik sekali. Untuk ketepatan kata dan struktur kalimat sudah baik namun tetap perlu

24 Agus Trianto, Pembahasan Tuntas Kompetensi Bahasa Indonesia Untuk SMP Dan Mts ditingkatkan kembali. Dua mahasiswa ini memiliki kendala yang sama yaitu saat di awal membaca pengumuman, masih lantang dan intonasinya tepat. Namun mendekati akhir pembacaan pengumuman, intonasi semakin menurun dan suara semakin pelan, sehingga pengumuman tidak dibacakan layaknya sebuah pengumuman dibaca dengan keras.

\subsection{Praktik Berpidato}

Pidato adalah seni berbicara dalam komunikasi yang lebih formal, terstruktur, berdaya jangkau luas guna menyampaikan gagasan dan perasaan yang lebih kompleks yakni dengan

Kelas VII, ed. Tim Editor Bahasa Esis (Penerbit Erlangga, 2007). 
berbicara di depan orang banyak. ${ }^{25}$ Dalam praktik berpidato, mahasiswa diminta untuk membaca teks pidato yang didalamnya terdapat struktur teks berupa pembukaan, penghormatan, isi, dan penutup. Seseorang yang berpidato memiliki tujuan untuk menyampaikan gagasan atau sekedar menyampaikan informasi atau pengetahuan yang perlu diketahui oleh pendengarnya . Aspek yang dinilai yaitu (1) kejelasan vokal; (2) ketepatan intonasi; (3) ketepatan pilihan kata (diksi); dan (4) struktur kalimat (tuturan) sama dengan aspek pada membaca cerita dan membaca pengumuman.

Tabel 4. Praktik Berpidato

\begin{tabular}{|c|c|c|c|}
\hline \multirow{2}{*}{ No } & \multirow{2}{*}{ Aspek Penilaian } & \multicolumn{2}{|c|}{ Kode Mahasiswa } \\
\hline & & $\mathrm{PI}_{1}$ & PI 2 \\
\hline 1. & Kejelasan vokal & 4 & 2 \\
\hline 2. & Ketepatan intonasi & 4 & 2 \\
\hline 3. & Ketepatan pilihan kata & 3 & 3 \\
\hline 4. & Struktur kalimat & 3 & 3 \\
\hline & TOTAL & 14 & 10 \\
\hline
\end{tabular}

Keterangan nilai:

4 : baik sekali

3 : baik

2 : cukup

1 : kurang

Berdasar tabel 4 diketahui jika mahasiswa PI 1 memiliki kemampuan yang baik sekali dalam aspek kejelasan vokal dan ketepatan intonasi. Kedua hal ini cukup penting bagi seseorang yang melakukan pidato. Untuk dua aspek lainnya yaitu ketepatan diksi dan struktur kalimat, mendapat nilai baik untuk kedua mahasiswa. Hal ini terjadi karena mahasiswa membuat dengan baik teks pidato dengan cermat. Karena dalam pidato, kemampuan untuk memilih diksi yang baik juga cukup memberikan efek yang signifikan bagi pendengarnya. Seseorang yang berpidato mempunyai misi penting yaitu menyampaikan informasi.

\footnotetext{
${ }^{25}$ Zaky Mubarok, "Pengaruh Minat Membaca Dan Penguasaan Kosakata Terhadap Keterampilan Berpidato Survey Pada Siswa Man Di Jakarta," Jurnal Mandiri 2, no. 1 (2018): 201-25, https://doi.org/10.33753/mandiri.v2i1.39.
}

Pada mahasiswa PI2 yang mendapat nilai kurang pada aspek kejelasan vokal dan struktur kalimat. Dalam praktiknya, mahasiswa ini gelagapan atau tidak siap serta tidak lancar dalam membaca teks pidato. Kedaan tersebut juga ditambah dengan intonasi yang tidak tepat dan suara yang cukup lirih untuk sebuah pidaro. Hasil yang demikian tentu tidak diharapkan jika nantinya kemampuan berbicara tersebut digunakan dalam kehidupa nyata.

\subsection{Praktik Berdiskusi}

Diskusi dimaknai oleh Suryosubroto dalam Firmansyah ${ }^{26}$ sebagai percakapan ilmiah oleh satu kelompok yang terdiri dari beberapa orang, untuk saling

\footnotetext{
26 Mochamad Bayu Firmansyah, "MODEL PEMBELAJARAN DISKUSI BERBASIS PERILAKU BERLITERASI UNTUK KETERAMPILAN BERBICARA_BAYU_sept_2017,"' 2018, 119-25, https://doi.org/10.31227/osf.io/ebx9j.
} 
bertukar pendapat mengenai sebuah masalah atau mencari bersama pemecahan sebuah masalah demi mendapatkan jawaban. Berbeda dengan 3 praktik berbicara lain, pada praktik berdiskusi, siswa tidak bisa mempraktekkannya secara individu melainkan berkelompok tiga mahasiswa. Dua mahasiswa menjadi pembahas, dan 1 orang menjadi moderator. Praktik berdiskusi sebenarnya sering dilakukan dalam kehidupan nyata. Banyak situasi dan keadaan yang membuat seseorang akan melakukan diskusi dengan orang yang lain demi membahas sesuatu yang sedang hangat untuk dibahas atau sekadar melakukan diskusi ringan. Dalam praktik berdiskusi, selain berbicara, mahasiswa juga diharuskan mendengarkan atau menjadi pendengar bagi lawan bicara dan juga moderator sebagai penengah.

Tabel 4. Praktik Berdiskusi

\begin{tabular}{|c|c|c|c|c|c|c|c|}
\hline \multirow{2}{*}{ No } & \multirow{2}{*}{ Aspek Penilaian } & \multicolumn{6}{|c|}{ Kode Mahasiswa } \\
\hline & & DI 1 & DI 2 & DI 3 & DI 4 & DI 5 & DI 6 \\
\hline 1. & $\begin{array}{c}\text { Kelancaran menyampaikan } \\
\text { pendapat/tanggapan }\end{array}$ & 4 & 4 & 4 & 3 & 3 & 3 \\
\hline 2. & Kejelasan vokal & 4 & 3 & 4 & 3 & 3 & 4 \\
\hline 3. & Ketepatan intonasi & 3 & 4 & 4 & 3 & 3 & 3 \\
\hline 4. & Ketepatan pilihan kata & 3 & 4 & 3 & 3 & 3 & 3 \\
\hline 5. & Struktur kalimat & 4 & 4 & 3 & 3 & 3 & 3 \\
\hline 6. & $\begin{array}{l}\text { Ketepatan mengungkapkan } \\
\text { gagasan disertai data tekstual }\end{array}$ & 4 & 4 & 4 & 4 & 4 & 4 \\
\hline & TOTAL & 22 & 23 & 22 & 19 & 19 & 20 \\
\hline
\end{tabular}

Keterangan nilai:

$4 \quad$ : baik sekali

3 : baik

2 : cukup

1 : kurang

Berdasarkan hasil penilaian praktik diskusi, dari dua kelompok diketahui ada perbedaan pada aspek kelancaran dalam penyampaian pendapat, pilihan kata, dan struktur kalimat, Berbeda dengan tiga praktik berbicara selain diskusi yang mengacu pada sebuah teks, dalam praktik diskusi kemampuan mahasiswa dalam berbicara lebih terlihat karena mereka membahas sebuah tema yang kemudian didiskusikan tanpa ada teks yang bisa dijadikan acuan. Hal ini yang kemudian membuat mahasiswa yang tidak memiliki kemampuan yang mumpuni dalam menyampaikan pendapat akan mengalami kesulitan.
Pada Tabel 5 diketahui ada mahasiswa yang memiliki nilai hampir sempurna yaitu DI 2 yang mendapat nilai total 23 dan hanya satu aspek yang tidak mendapat nilai penuh yaitu kejelasan vokal. Hal ini karena suara saat berdiskusi kurang lantang padahal mampu menjawab dengan baik, hanya mungkin masih merasa malu untuk bersuara lebih keras walaupun tidak disaksikan langsung oleh pendengar namun hanya dengan pesan suara. 


\subsection{Kendala Pembelajaran \\ Keterampilan Berbicara dengan \\ Media Pesan Suara}

Dalam pembelajaran tentu selalu ada kendala yang dialami oleh pengajar maupun pembelajar, baik terkait materi, teknik, model, maupun media pembelajaran. Pembelajaran keterampilan berbicara yang dilaksanakan dalam jaringan, tentu juga memiliki kendala yang mengakibatkan pelaksanaan pembelajaran tidak dapat berjalan secara maksimal. Di antara kendala tersebut antara lain:

a. Penggunaan media elektronik telepon seluler tentu selalu terkendala dengan jaringan seluler atau sinyal yang tidak selalu stabil dalam pengoperasiannya.

b. Pesan yang disampaikan tidak dapat maksimal karena tidak bisa mengontrol suara yang dikirimkan dengan tepat.

c. Hanya bentuk audio yang dapat diterima tanpa adanya visualisasi berupa video atau gambar, terkadang membuat pesan yang tersampaikan tidak sepenuhnya tepat dengan tujuan di awal.

d. Tidak dapat dilihatnya ekspresi si pengirim pesan karena tidak ada kontak mata dengan pendengar membuat kesan dari pesan tersebut terasa kehilangan "nyawa" jika tidak diiringi dengan intonasi yang tepat dan kejelasan vokal yang baik.

e. Dosen tidak dapat melihat secara langsung ekspresi dan cara mahasiswa tersebut melakukan praktik sehingga penilaian tidak dapat dilakukan secara maksimal karena hanya dengan mendengar suara saja dari pesan suara.

f. Mahasiswa yang tidak praktik tidak bisa menjadi pendengar secara langsung saat mahasiswa yang sedang praktik berbicara, namun harus terjeda oleh waktu pengiriman pesan suara yang membutuhkan beberapa detik hingga menit jika terjadi kesalahan jaringan.

\section{Simpulan}

Pembelajaran bahasa pada masa pandemic tentu tidak mudah dengan diwajibkannya pembelajaran jarak jauh secara daring sehingga banyak praktik pembelajaran yang kurang maksimal. Penggunaan media pembelajaran yang sesuai juga merupakan solusi yang ditawarkan demi tetap berjalannya pembelajaran, termasuk dengan menggunakan pesan suara sebagai media pembelajaran dalam praktik keterampilan berbicara. Dalam komunikasi terutama lisan, maka kemampuan seseorang dalam berbicara adalah kemampuan yang perlu dikuasai dengan baik oleh seseorang. Sebagai seorang calon guru, mahasiswa dituntut untuk memiliki kemampuan berbicara yang baik merupakan hal yang harus dikuasai oleh seorang guru. Seorang guru perlu memiliki kemampuan yang baik dalam berbicara baik dalam penguasaan teori maupun dalam praktiknya di kehidupan sehari-hari.

Praktik pembelajaran keterampilan berbicara dilakukan dengan dengan empat jenis praktik berbicara yaitu membaca cerita, membaca pengumuman, berpidato, dan berdiskusi. Dari empat praktik tersebut diketahui jika tidak praktek berbicara yaitu membaca cerita, membaca pengumuman, dan berpidato hanya melibatkan 4 aspek penilaian yaitu (1) kejelasan vokal; (2) ketepatan intonasi; (3) ketepatan pilihan kata (diksi); dan (4) struktur kalimat (tuturan). Hal ini dikarenakan tidak ada interaksi yang dilakukan dengan pembicara lain, tidak perlu menyampaikan atau mengemukakan pendapat, dan tidak 
diwajibkan menunjukkan data di luar isi teks naskah untuk mendukung kemampuan berbicaranya. Berbeda dengan kemampuan diskusi yang menuntut adanya 6 aspek yaitu (1) kelancaran menyampaikan pendapat/tanggapan; (2) kejelasan vokal; (3) ketepatan intonasi; (4) ketepatan pilihan kata (diksi); (5) struktur kalimat (tuturan); dan (6) ketepatan mengungkapkan gagasan disertai data tekstual dalam praktiknya. Pada praktik diskusi juga kemampuan mahasiswa dalam berbicara dilatih lebih baik tanpa ada ketergantungan pada teks bacaan. Namun masih terdapat satu aspek yang tidak bisa dilibatkan dalam penilaian praktik pembelajaran dari dengan media pesan suara yaitu kontak mata dengan pendengar. Satu aspek ini juga yang kemudian menjadi salah satu kendala yang dihadapi pada pembelajaran daring yang hanya menggunakan media pesan suara dalam pembelajarannya. Tidak dapat diketahuinya ekspresi dan gesture saat melaksanakan praktik juga membuat pendengar (dosen) tidak memasukkan ke dalam aspek penilaian.

\section{Daftar Pustaka}

Ahyar, Hardani, Universitas Sebelas Maret, Helmina Andriani, Dhika Juliana Sukmana, Universitas Gadjah Mada, M.Si. Hardani, S.Pd., Grad. Cert. Biotech Nur Hikmatul Auliya, et al. Buku Metode Penelitian Kualitatif $\mathcal{E}$ Kuantitatif, 2020.

Bloomfield, Leonard. An Introduction to The Study of Language. New York: Henry Holt and Company, 1914.

Darmalaksana, Wahyudin, R. Yuli Ahmad Hambali, Ali Masrur, and Muhlas. "Analisis Pembelajaran Online Masa WFH Pandemic Covid-19 Sebagai Tantangan Pemimpin Digital Abad 21." Karya Tulis Ilmiah (KTI) Masa Work From Home (WFH) Covid-19 UIN Sunan Gunung Djati Bandung
Tahun 2020 1, no. 1 (2020): 1-12.

Direktorat Jenderal Pendidikan Tinggi

Kemdikbud RI. "Buku Panduan

Penyelenggaraan Pembelajaran

Semester Gasal 2020/2021 Di

Perguruan Tinggi," 2020, 29.

Firmansyah, Mochamad Bayu. "MODEL

PEMBELAJARAN DISKUSI BERBASIS

PERILAKU BERLITERASI UNTUK

KETERAMPILAN

BERBICARA_BAYU_sept_2017," 2018,

119-25.

https://doi.org/10.31227/osf.io/ebx9j.

Hanum, Numiek Sulistyo. "Keefektifan E-

Learning Sebagai Media

Pembelajaran (Studi Evaluasi Model

Pembelajaran e-Learning SMK

Telkom Sandhy Putra Purwokerto).”

Jurnal Pendidikan Vokasi 3, no. 1 (2013):

90-102.

https://doi.org/10.21831/jpv.v3i1.1584.

Jamaludin. "Kendala Pembelajaran Daring

Di Tengah Pandemi Covid-19." In

Belajar Mandiri: Pembelajaran Daring

Di Tengah Pandemi Covid-19, edited

by Janner Simarmata, 107-12. Yayasan

Kita Menulis, 2020. kitamenulis.id.

Kusmintayu, Norma, Sarwiji Suwandi, and Atikah Anindyarini. "Penerapan Metode Mind Mapping Untuk Meningkatkan Keterampilan Berbicara Pada Siswa Sekolah Menengah Pertama." Jurnal Penelitian Bahasa, Sastra Indonesia, Dan Pengajarannya 1, no. 1 (2012): 120-29.

Lailiyah, Nur, and Widi Wulansari. "Peningkatan Keterampilan Berbicara Melalui Metode Diskusi Kelompok Model Tanam Paksa Siswa Kelas X Pemasaran 1 SMK PGRI 2 Kediri." JP (Jurnal Pendidikan): Teori Dan Praktik 1, no. 2 (2017): 166-73.

Marriam Bashir; Muhammad Azeem; Ashiq Hussain Dogar. "Factor Effecting Students' English Speaking Skills." British Journal of Arts and Social Sciences 2, no. January 2011 
(2016): 35-50.

Mubarok, Zaky. "Pengaruh Minat Membaca Dan Penguasaan Kosakata Terhadap Keterampilan Berpidato Survey Pada Siswa Man Di Jakarta." Jurnal Mandiri 2, no. 1 (2018): 201-25. https://doi.org/10.33753/mandiri.v2i1. 39.

Ningsih, Suwarti. "Peningkatan Keterampilan Berbicara Melalui Metode Bercerita Siswa Kelas III SD Negeri 1 Beringin Jaya Kecamatan Bumi Raya Kabupaten Morowali." Jurnal Kreatif Tadulako Online 2, no. 4 (2013): 243-56.

Nugrahani, Farida. Metode Penelitian Kualitatif Dalam Penelitian Pendidikan Bahasa. Cakra Book. Vol. 1. Solo, 2014.

Nurgiyantoro, Burhan. Penilaian Dalam Pengajaran Bahasa Dan Sastra Indonesia. Yogyakarta: BPFE, 2001.

Putria, Hilna, Luthfi Hamdani Maula, and Din Azwar Uswatun. "Analisis Proses Pembelajaran Dalam Jaringan (DARING) Masa Pandemi COVID-19 Pada Guru Sekolah Dasar." BASICEDU 4, no. 4 (2020). https://doi.org/10.31004.

Setianto, Akbar Yuli. "Kurikulum
Fleksibel : Jalan Keluar Pembelajaran Di Masa Covid-19." In Belajar Mandiri: Pembelajaran Daring Di Tengah Pandemi Covid-19, edited by Jamaludin. Yayasan Kita Menulis, 2020. kitamenulis.id.

Sholihah, Rizki Amalia. "Metode Suggestopedia Dengan Teknik Bermain Peran Atau Role Playing Dalam Pembelajaran Keterampilan Berbicara Bahasa Indonesia Siswa Sekolah Dasar." Al-Adabiya: Jurnal Kebudayaan Dan Keagamaan 10, no. 1 (2017): 1-24.

Sintadewi, Ni Gusti Ayu, Sang Ayu Putu Sriasih, and I Nyoman Sudiana. "Teknik Penilaian Keterampilan Berbicara Dalam Pembelajaran Bahasa Indonesia Di SMA Negeri 4 Denpasar." E-Journal Pendidikan Bahasa Dan Sastra Indonesia 7, no. 2 (2017): 1-12.

Trianto, Agus. Pembahasan Tuntas Kompetensi Bahasa Indonesia Untuk SMP Dan Mts Kelas VII. Edited by Tim Editor Bahasa Esis. Penerbit Erlangga, 2007. 